\title{
Thinking the 'Culture Wars' and the Present Political Crisis with the Young Marx (and Friends)
}

\author{
Ben Whitham \\ De Montfort University, Leicester, UK, ben.whitham@dmu.ac.uk
}

\begin{abstract}
We stand at a key juncture: a Western political crisis arose in 2016-17 to match the deep economic crisis of the preceding decade. Events and new social movements of recent years seem to hail the collapse of the project of liberal democracy, though it is hard to see what will replace it. Among the conceptual and analytic tools bequeathed by Marx are those necessary to better understand and anticipate the direction of this key historical moment - from Donald Trump, Brexit and the so-called 'culture wars' to the horizon of liberal democracy itself. In this reflection, I suggest some ways in which Marx's early thoughts on the liberal state and civil society can and should help us to better understand and explain our present predicament. To say that the Young Marx can help us today with what he called 'the ruthless critique of everything existing' is not to say that he can do so alone. It is precisely the issues overlooked or 'fudged' by Marx and Marxism - gender, sexuality, and race/racism for example - that now sit at the centre of our 'culture wars', alongside but never reducible to the contradictions and crises of capitalism. I conclude that it is only with the help of other writers of the 20th and 21st centuries, from Antonio Gramsci to Frantz Fanon and bell hooks, that we can usefully mobilise the Young Marx today, to critique the world as we find it and especially - the very 'point' of theory according to Marx - to change it.
\end{abstract}

Keywords: Young Marx, culture wars, intersectionality, bell hooks

"You also had people that were very fine people, on both sides" -- President Donald Trump, 2017.

"Political emancipation was at the same time an emancipation of civil society from politics and from even the semblance of a general content" -- The 'Young' Karl Marx, 1843.

\section{Introduction}

Donald Trump's response to reporters at a press conference following the murder of antifascist demonstrator Heather Heyer at the Charlottesville "Unite the Right" march by the neo-Nazi James Alex Fields Jr. was emblematic of the present political crisis. The political mainstream responded to Trump's claim that there were "very fine people, on both sides" with outrage. Not only liberal and left wing commentators and politicians, but also conservative Republicans including House Speaker Paul Ryan, expressed disgust. The BBC North America correspondent James Cook later suggested that Trump's comments gave "succour to the far right", and approvingly cited Mitt Romney's tweet in response: "No, not the same. One side is racist, bigoted, Nazi. The other opposes racism and bigotry. Morally different universes" (Cook 2017). Yet a BBC article entitled "America's Extremist Battle: Antifa V Alt-Right", published just six months before Charlottesville, had drawn an identical moral equivalence to that mobilised by Trump. There, the BBC described anti-fascists and the neo-fascists styling themselves "alt-right" as "two groups at the extreme ends of the political spec- 
trum" (Yates 2017). Their use of violence rendered the two groups morally equivalent "extremists", according to this view. So what changed?

The BBC has been one of many fronts in the so-called 'culture wars'. Accused of peddling "fake news" by the Trump administration early in 2017 (BBC News 2017a), of "pro-remain bias" by Brexit supporters (Maddox 2017), and of anti-Corbyn bias by the Labour left - the latter at least partly substantiated by the BBC Trust, which found that political editor Laura Kuenssberg "broke accuracy and impartiality rules in a News at Six report about Jeremy Corbyn" (BBC News 2017b). These are seemingly extraordinary accusations for an organisation that prides itself on 'neutrality'. But Tom Mills gets to the heart of the BBC's ideological 'neutrality' in his analysis of structural bias against Corbyn: "Corbynism seeks to develop a political movement that can transcend neoliberalism. It therefore finds itself at odds with the prevailing culture of the contemporary BBC, which in any case has always been orientated towards mainstream politics" (Mills 2017). Political 'neutrality', as any first-year undergraduate student of politics should be able to tell you, is an impossibility. At the BBC it really consists of giving equal coverage to dominant forces within the boundaries of mainstream, status quo party politics. It is of course not alone in this - an LSE study of newspapers found that bias against Corbyn was widespread and systematic (Cammaerts et al. 2016).

Traditional media have struggled with the notion that a politician representing a project so 'other' to the neoliberal norm should be treated with any seriousness at all, let alone respect. Similarly, while Trump's comments made the absurdity of taking a 'neutral' position on the rise of fascism inescapable to even the BBC, their earlier coverage of antifa and the alt-right drew a moral equivalence because political violence (their story had been inspired by the much-publicised punching of neo-Nazi Richard Spencer by a masked anti-fascist) situated both movements outside the sphere of 'normal' politics.

The political crisis experienced by the West today - with Trump and Brexit its two most powerful emblems, but Corbyn, Bernie Sanders, Black Lives Matter, \#MeToo and myriad other individuals and movements also at stake - is the endgame of neoliberalism and signals the fundamental limits of the liberal democratic state itself. The 'normal' politics of Western liberal democracies has been on a tapering trajectory, growing ever narrower; the only qualification for fitting within that normal politics being that one represents the (class, race, gender, sexual, cultural) politics of accepting neoliberal norms - what Mark Fisher calls "capitalist realism" (2009). That means accepting not only the privatisations and marketisations of public industries, goods and spaces, but also certain "moral" prohibitions - on raising income tax on high earners or corporation tax on big businesses, both of which are characterised as the real "wealth creators" in neoliberal societies (Whitham 2015).

What the culture wars have so starkly revealed is the horizon of this neoliberal politics and of the liberal democratic state. In his essay "On the Jewish Question", the 'Young Marx' notes how the transition from feudalism and the rise of the bourgeoisie to the status of a ruling class effectively created a "political" state predicated on the "rights of man", but in which a depoliticisation is underway through the creation of civil society. This emancipation and the political "freedom" the Enlightenment engendered was always inherently limited, and its contradictions were bound eventually to be revealed. The bifurcation of our social selves that the liberal democratic state model achieves, the internal schism between the self as a member of a political community and the self as "private" individual, a member of civil society, results, as the Young Marx saw, not in the abolition of religiosity but in its reincarnation. As long 
as such a split defines our social life, our ability to make meaningful political progress is curtailed and our political culture becomes an ever-narrower domain. 'Normal' politics is reduced to choices between policy-tweaks: to questions of how the state can better facilitate the relationship between the privatised, atomised citizen-as-consumer - the member of civil society - and the market. It is in this political vacuum, this loss of meaningful debate over how we could and should live together as societies, that our present political crisis was born. In this reflection, I therefore draw upon key texts and concepts of the Young Marx to highlight how he anticipated the present crisis.

But the Young Marx is not enough to explain and especially to change the direction of travel of Western (neo)liberal democracies today; and of course the Young Marx would have us not only 'interpret' the world when "the point is to change it". The social movements of resistance which have led us to the present confrontation with the liberal democratic state embody anti-racist, anti-colonial, anti-patriarchal, and antiheteronormative values in ways that Marx - young or mature - simply could not account for. Here I reach out to 'friends'. These friends - Antonio Gramsci, Frantz Fanon and bell hooks - are sympathetic to, but not constrained by, Marxist thought. It is, in my view, essential to incorporate the reflections of such friends if we are to make the most of Marx's thought today.

\section{The "Culture Wars" and the Present Political Crisis}

Trump's election has been viewed as both a product and a propagator of "the culture wars" (for example: Nagle 2017). These so-called "wars" have consisted partly of a revival of left and right wing political cultures that were marginalised or repressed during the allegedly post-ideological 'happy 90s', and a conflict being played out between them; largely in the digital spaces of social media and online forums, from 4chan to Twitter. The association of the so-called 'alt-right' with such activity has, however, led to confusion. Neo-Nazis across the West have been identified as - and many now actively seek identification as - 'alt-right'.

The core project of the racist and neo-Nazi groups and individuals styling themselves 'alt-right' has been one of opposing a wide range of 'liberal' and 'left' political positions, especially feminisms, along with women, and all minority ethnicities, gender identities and sexualities. To the extent that we might wish to recognise the existence of "culture wars", they consist in confrontations between these far-right movements, old and new, and the left-wing, feminist, anti-racist and other activists and intellectuals they despise. But an important third party to this transnational conflict has been the self-proclaimed 'centrist' movement that seeks a return to the failed and irretrievable neoliberal norm - the so-called 'centrist dads' who continue to appeal to the contradictory normative schema of neoliberalism, while denouncing all forms of radical politics (left, right, and feminist). This "centrist ancien regime" (Lemmey 2018) consists of mostly white, professional, middle/upper-middle class men, often working in political journalism or research, who simply cannot accept that their dogma might have ceased to determine the horizons of normal politics, since they only ever understood it as a pragmatic approach to 'reality', and not as a partisan political project at all.

The culture wars represent a profound crisis of the neoliberal state. The strategies and discourses of depoliticisation advocated by neoliberal thinkers like Friedrich Hayek and Milton Friedman, and perfected in practice not, as is often assumed, by Reagan and Thatcher, but through the 'Third Way' politics of Clinton and Blair, have begun to reach their logical conclusion. Through the transformation of formal politics in Western liberal democracies by prevailing ideas of 'pragmatism', 'public manage- 
ment', 'evidence-based policy' and so on, the Third Wayers sought to render the state, as Friedman once demanded, little more than "an umpire to interpret and enforce the rules" of the "game" of capitalism (Friedman 2002, 15): the interactions between citizens-as-consumers and the various markets providing them with goods and services (including formerly 'public' services). Increasingly, those seeking to use the state as a forum for actual political debate - debate about how we should live together as societies - were accused of 'ideology', of 'playing politics' with what are fundamentally economic, scientifically law-governed concerns (from basic human behaviour to the most appropriate, just or efficient way to spend tax revenues on public goods).

Of course, we were already in the grip of a crisis when Brexit, Trump and the culture wars arrived. The financial crash of 2007 had precipitated the widest and deepest international economic crisis since the 1930s. The Neoliberal Crisis (Davison and Harris 2015), a short collection of essays by the editors of the journal Soundings, originally published between 2009 and 2011, was extremely prescient with regard to the present political crisis (Whitham 2017). Contributor Doreen Massey noted that the economic crisis in the UK had yet to be matched by a "real crisis in the ideological formation" (Davison and Harris 2015, 182), while Stuart Hall and others highlighted the inescapably racialised and postcolonial aspects of neoliberalism, which exists "cheek by jowl with older conservative attachments to nation, racial homogeneity, Empire, tradition" (Ibid., 22). Michael Rustin, in an eerie foreshadowing of Trump's successful White House run, argued that while Obama's election (then in his first term as President) was heartening, representing "a source of hope", the Democrat continuation of the neoliberal project in office could prove so alienating as to ultimately "bring to office a president with a political outlook like that of Sarah Palin" (Ibid., 35). Through their Gramscian analysis of the crisis as a "conjuncture", these authors were able to foresee the Western political crisis that began to come to fruition in 2016. Decades of de-politicisation in the name of 'centrism', combined with deep austerity cuts dressed-up as inevitable and rational policy-making or as a 'belt tightening' moral obligation on ordinary people to absorb the costs created by irresponsible bankers, brought us to a point where ideological struggle - declared "dead" by Blair and others - finds its eternal return. The culture wars are a new left-right politics, played out across a range of old and new political fora (social and traditional media, campus speaking tours, and increasingly among politicians of the mainstream too).

So neoliberal depoliticisation in the name of 'free' market-governed sociality, along with neoliberal multiculturalism, which everywhere proclaims racial equality as its goal (Friedman was convinced that racism was a product of politics and could be eradicated by the cleansing purity of market mechanisms) while continuing colonial trajectories in practice, created the conditions for the present crisis. But its roots can be traced much further back. The Young Marx identified, at the very point of its birth, the horizon of what would become the neoliberal state.

\section{The Young Marx: Limits and Contradictions of the Liberal Democratic State}

It bears mentioning that the notion of a 'Young Marx' is, like most aspects of Marxist thought, a contested concept within the Marxist tradition itself. Louis Althusser was strongly opposed to what he saw as a "liberal" trend, instigated by "petty bourgeois" critics of Marxism and then taken up en masse by "Communist intellectuals" themselves, of developing "humanist" readings of Marx by appealing to his early works (Althusser 1969, 10-11). The Young Marx, from Althusser's perspective, "was merely 
applying the theory of alienation, that is, Feuerbach's theory of 'human nature', to politics and the concrete activity of man, before extending it (in large part) to political economy" (Ibid., 46). Essentially, the Althusserian objection is that the Young Marx was in fact not a Marxist, but a Feuerbachian humanist and ethicist. While Marxists like Althusser are right to be sceptical of humanist revisionism, they are constrained by a powerful commitment to its discredited opposite: scientism. It is quite possible to (critically) embrace and draw upon Marxism without either adhering to the notion that it is about generating "scientific knowledge [...] of history" (Ibid., 14) or abandoning the insights of Capital altogether in favour of a 'human nature'-centred account of alienation. Marx - and especially the Young Marx - was first and foremost concerned with Kritik; the critique of existing social "formations", as Althusser calls them. Those of us who seek to continue this practical-intellectual tradition should feel free enough to choose to apply those insights from Marx himself that are most appropriate to the specific social formation(s) we are critiquing (and indeed to splice other ideas into these insights as I do later in this paper). It is my - I hope uncontroversial - contention that to critically explain the contemporary political crisis and its "culture wars", the Young Marx on the origins and limits of the liberal democratic state is more useful than the mature Marx on, say, the fetishism of the commodity or the tendency of the rate of profit to fall.

"Bourgeois" revolutions like that which brought about American independence consisted, for the Young Marx, in a form of "political emancipation" that is "not the final and absolute form of human emancipation" (Marx 1978b/1843, 32). Such revolutions may have marked the decisive end of the divine right of kings and the shaking off of the last vestiges of feudal relations, but this transformation was also a fundamental ideological transformation of what was to be considered political. As Marx puts it in his essay "On the Jewish Question":

The state abolishes, after its fashion, the distinctions established by birth, social rank, education, occupation, when it decrees that birth, social rank, education, occupation are non-political distinctions; when it proclaims, without regard to these distinctions, that every member of society is an equal partner in popular sovereignty (Ibid., 33).

The 'political state', the birth of which the Young Marx was focused on, culminated in the contemporary (neo)liberal democracy. Western liberal democracies are societies in which state power is exercised in the name of equality ('equality before the law', 'equal rights' and so on) but in the actual material service of inequality (the exploitation and cultural demonisation of working-class people, people of minority ethnic backgrounds, and of women). "Liberty" in liberal states conceived as "the right to do everything which does not harm others", is, the Young Marx argues, "not founded upon the relations between man and man, but rather upon the separation of man from man. It is the right of such separation. The right of the circumscribed individual, withdrawn into himself" (Ibid., 42). The central contradiction to which the Young Marx pointed is thus a state of affairs wherein people, freed from the social bonds of feudalism and rendered political actors through the emergence of 'civil society' are simultaneously barred from engaging in any meaningful politics since the end state of human emancipation is assumed to already be achieved, and "the political character of civil society" is in fact "abolished" (Ibid., 45), its constituents reduced to "man regarded as an isolated monad" (Ibid., 42). When he writes that the transition from feudalism to truly capitalist societies involved the "emancipation of civil society from poli- 
tics" (Marx 1978b/1843, 45), the Young Marx's point is that the ostensible politicisation of society in the creation of the liberal democratic state in fact contains within it a de-politicisation.

This dialectical reading of the Young Marx, wherein the liberal democratic state formation contains the seed of its own destruction, allows us to look further back, well beyond the dawn of the present crisis, or even the neoliberal acceleration of depoliticisation, and to see the de-politicising tendency in the very form of the liberal states created by the bourgeois revolutions.

Politics as expressed in civil society are, in the Young Marx's view, effectively a simulation predicated on abstraction and alienation. This is nowhere truer than in neoliberal societies after what Francis Fukuyama (in)famously called the "End of History". The political, in these societies, is circumscribed to an ever-narrowing range of positions, since the economic base of such societies is not up for debate. Not only the "political economists" targeted by the Young Marx in the Manuscripts, but also all mainstream politicians and viable political parties, adopted the position that "every individual is a totality of needs and only exists for the other person, as the other exists for him, in so far as each becomes a means for the other" (Marx 1978c/1844, 101). This is precisely the worldview informing the depoliticising neoliberal politics that brought us to the present crisis. We can think of the 'Third Way' politics and 'new public management' of the late twentieth century, indeed of the neoliberal turn, as the end point of the liberal democratic state.

\section{Friends of the Young Marx}

The Young Marx wrote, in a letter later known as "For a Ruthless Criticism of Everything Existing":

Apart from the general anarchy which has erupted among the reformers, each is compelled to confess to himself that he has no clear conception of what the future should be. That, however, is just the advantage of the new trend: that we do not attempt dogmatically to prefigure the future, but want to find the new world only through criticism of the old (Marx 1978a/1843, 13).

This spirit of radical openness, in striking contrast to the historical scientism and determinism that would become characteristic of much Marxist thought, is especially useful for thinking about how we can engage the Young Marx today. "Criticism of the old" world today necessarily includes criticism of Marx and Marxism. Both have suffered from blind spots, especially on the intersectional but irreducible character of social formations of domination, inequality and exploitation. Feminists especially, but also many anti-racist and post-colonial scholars, have persistently pointed to the failure of Marx and Engels to treat issues of gendered and racial inequality and domination as anything more than epiphenomenal of economic modes of production. This economistic reductionism is inadequate to grasp our present situation. And it is for this reason that I now want to enlist some 'friends' of Marx to shed further light on the crisis and its direction.

The friends of Marx I refer to here - Gramsci, Fanon and hooks - constitute by no means an exhaustive or representative sample. To list sympathisers with and developers of Marx(ism) in the fields of these three authors alone - critical social theory, anti/post-colonial and psychoanalytic theory, and intersectional feminism - would be a massive endeavour. Instead I have chosen three authors who I feel speak espe- 
cially to the spirit of the Young Marx, and whose insights can be made to speak to the present crisis.

Antonio Gramsci's contribution to Marxist thought has been elaborated in great detail by many authors, over many years. But for understanding the culture wars and the direction of the present crisis, there are a few crucial points it is worth briefly unpacking here. In his refutation of the "economistic superstition" (Gramsci 1999/1916$1935,215)$ inherent to popular early 20th-century interpretations of Marxism, Gramsci insists that: "It is therefore necessary to combat economism [...] especially in the theory and practice of politics. In this field the struggle can and must be carried on by developing the concept of hegemony" (Ibid., 216). Like the Young Marx, Gramsci is concerned with the "distinction between political society and civil society, which is made into and presented as an organic one" by liberalism (Ibid., 210) but he sees a similar fallacy being committed by the economistic Marxists of the Second International. Gramsci asks us to recall that for Marx, the struggle that should result in class consciousness must take place "on the terrain of ideologies" (Ibid., 213). The neoliberal hegemony that the "centrist ancien regime" mentioned above seeks to protect or restore through their role in the culture wars consists of a set of "common sense" discourses about politics and economy since, in a "discursive sense, there is a struggle for hegemony, which is played out on the terrain of common sense" (Donoghue 2017, 9).

But the contradictions of Western liberal-democracy run deeper than capitalism. In his classic The Wretched of the Earth, the Algerian revolutionary and psychoanaIytic theorist and practitioner Frantz Fanon writes:

The violence with which the supremacy of white values is affirmed and the aggressiveness which has permeated the victory of these values over the ways of life and of thought of the native mean that, in revenge, the native laughs in mockery when Western values are mentioned in front of him (Fanon 1967/1961, 33).

In postcolonial Western societies, as in the colonised societies Fanon sought to understand and emancipate, the structures and privileges of 'civil society' have never been universal; they are not extended to the black and the brown, to the colonial and postcolonial subjects. The left, Paul Gilroy notes in his introduction to Fanon's other key work, Black Skin, White Masks (2017/1952) "despaired at Fanon's deviations" from Marxist orthodoxy, finding "its own economistic logic disputed by his deeper sense of the sociogenesis of racial inequality" (Ibid., xvii). Marx, it must be recognised, was as much a product of the "European culture" that Fanon understood to function "as a means of stripping himself [Fanon] of his race" (Ibid., 192) as any other Western intellectual of the 19th century. Crucially, unlike Marx, Fanon's enquiries into the (post/anti) colonial led him to find that "scientific objectivity was barred to me, for the alienated, the neurotic, was my brother, my sister, my father" (Ibid., 193). And so Fanon's work was essentially a form of what is sometimes called 'standpoint theory' today. In other words, Marx - as a Great White Man of European intellectual history may not provide us with all the tools we need to understand the experiences of those subjugated by social relations of structured inequality other than the bourgeoisproletarian one.

So, to account for the present crisis - indeed the whole trajectory of Western history - through Marx alone would be insufficient. At the heart of the crisis and especially the culture wars that brought Donald Trump to power are postcolonial issues: 
Police shootings of unarmed black men in the United States and the emergence of Black Lives Matter as a transnational social movement, the '\#RhodesMustFall movement on campuses from South Africa to the UK, the systematic demonisation and harassment of Muslims in the West as part of the so-called "War on Terror", the attempted removal of statues of the slave-owner and Confederate General Robert E. Lee that triggered the Charlottesville neo-Nazi demonstrations and antifascist counter-demonstrations. Neither the Young Marx's critique of the liberal state nor the mature Marx's critique of capitalism is sufficient for a critical engagement with all of this.

In many of her works, the feminist theorist, pedagogical innovator and cultural critic bell hooks uses the helpful term "white supremacist capitalist patriarchy" when referring to American (and, we can infer, more broadly "Western") society (hooks 1982; $2000 / 1984 ; 1994)^{1}$. Though something of a mouthful, this label is useful because it pinpoints with laser-sharp accuracy three of the core intersecting structural logics that underpin the Western liberal-democratic social model. By continuously referring to white supremacist capitalist patriarchy across her works, despite how cumbersome the phrase is, hooks also brilliantly emphasises the fundamental contradictions and hypocrisies at the heart of more common, euphemistic labels for such societies, including 'liberal democracies'.

Apart from the concept of white supremacist capitalist patriarchy, hooks transcends both Marx and the other 'friends' I have alluded to in a further crucial sense. Devoid of both the macho posturing and the scientism that has afflicted so much writing by the "Great White Men" of social theory - Marx and Gramsci included - hooks is able to speak seriously of the importance of love and community in social movements and society at large (hooks 1994, 263). The cultural trajectory of Enlightenment Man that underpinned the writings of the young and especially the mature Marx is shared with the 'centrist dads' and anti-feminist social media trolls of the culture wars (i.e. the mostly middle-aged, mostly white men who use social media as a platform to seek to publicly discipline women's knowledge through appeals to 'science' and facticity), a good number of whom identify as left-wing. Uncompromising and intellectually brilliant, hooks nevertheless consciously strives to render her work accessible (lbid., 8) and meaningful to people outside of academia, especially women of colour like herself. While hooks has been accused by some (including White Feminists) of being "merciless" (hooks 2000/1984, xiii), she writes with care and love as much as anger. This extends to hooks' pedagogical theory too - teaching, for hooks, is about creating space for all voices in the classroom, creating conversations and dialogue in place of lectures and the one-way "banking" model of education. I mention this because hooks' work - both her social and her pedagogical theories and analyses - provides clues to the way forward, to the politics that must come after the culture wars, after capitalism. What the left should surely be struggling for in the culture wars is a politics of love, a politics that recognises the intersectionality of inequalities and domination, rather than re-inscribing those very inequalities in leftist form by marginalising feminist, anti-racist and transgender recognition struggles in favour of economistic reductionism.

${ }^{1}$ hooks initially coined the term "white capitalist patriarchy" (a modification of Zillah Eisenstein's socialist feminist term "capitalist patriarchy") in her debut book Ain't I a Woman? (hooks 1982) but later added the "supremacist" in Feminist Theory: From Margin to Center (1984/2000). In some of her later work, when stressing the international dimensions of Western regimes, hooks opts for "imperialist white supremacist capitalist patriarchy". I prefer not to add the "imperialist" since this dimension can arguably be adequately captured by both "white supremacist" and "capitalist". 


\section{Conclusion}

This reflection on how the Young Marx can help us to think about the present political crisis and its so-called "culture wars" is intended to provoke as much as to pay tribute. That 200 years since his birth, this figure can still be rendered pertinent, vital even, to our theorisations, critiques and analyses of crises as if we are "haunted by Marx's ghost still rattling around in the theoretical machine" (Hall 1986, 32), speaks to the power of his ideas and the eloquence of his writing. But to imagine that our present political crisis could be accounted for with a close reading of Capital would be a mistake. Patriarchy, misogyny, heteronormativity, racism, and Islamophobia - the structures and ideologies underpinning liberal democracies viz. white supremacist capitalist patriarchies - have other sources than modes of production, and fulfil other social functions than bourgeois exploitation of the proletariat.

What I have sought to show is both what the Young Marx can offer us today and the conditionality we ought to impose upon this offer. We can only usefully deploy Marx to understand our present political crisis if we do so in conjunction with 'friends' like those I discuss above. From Antonio Gramsci to bell hooks, we need to bring more voices to bear on our problem, to better understand the dynamics and debates among emergent and ascendant social movements. This theoretical and analytic heterogeneity is essential if we want not only to interpret the world but also to change it.

\section{References}

Althusser, Louis. 1969. For Marx. London: Allen Lane.

BBC News. 2017a. Donald Trump Aide Accuses BBC of "Fake news". Accessed 05 January 2018. http://www.bbc.co.uk/news/av/world-us-canada-39000118/donald-trump-aideaccuses-bbc-of-fake-news

BBC News. 2017b. Laura Kuenssberg Report on Jeremy Corbyn Inaccurate, Says BBC Trust. Accessed 05 January 2018. http://www.bbc.co.uk/news/entertainment-arts38666914

Cook, James. 2017. Giving Succour to the Far Right, Trump Breaks With American Ideals'. BBC News. Accessed 05 January 2018. http://www.bbc.co.uk/news/world-us-canada$\underline{42197006}$

Davison, Sarah and Katherine Harris, eds. 2015. The Neoliberal Crisis. London: Lawrence \& Wishart.

Donoghue, Matthew. 2017. Beyond Hegemony: Elaborating on the Use of Gramscian Concepts in Critical Discourse Analysis for Political Studies. Political Studies, Online First, https://doi.org/10.1177/0032321717722362

Cammaerts, Bart, Brooks DeCillia, João Magalhães and César Jimenez-Martínez. 2016. Journalistic Representations of Jeremy Corbyn in the British Press: From Watchdog to Attackdog. Media@LSE Report. London: LSE.

Fanon, Frantz. 2017/1952. Black Skin, White Masks. London: Pluto Press.

Fanon, Frantz. 1967/1962. The Wretched of the Earth. London: Penguin.

Fisher, Mark. 2009. Capitalist Realism. Ropley: Zero Books.

Friedman, Milton. 2002. Capitalism and Freedom. Chicago, IL: Chicago University Press.

Gramsci, Antonio. 1999/1916-1935. The Antonio Gramsci Reader. London: Lawrence \& Wishart.

Hall, Stuart. 1986. The Problem of Ideology - Marxism without Guarantees. Journal of Communication Enquiry 10 (2): 28-44.

hooks, bell. 2000/1984. Feminist Theory: From Margin to Center. London: Pluto Press.

hooks, bell. 1994. Outlaw Culture. Abingdon: Routledge.

hooks, bell. 1982. Ain't I a Woman? Boston, MA: South End Press. 
Lemmey, Hugh. 2018. Tweet. Accessed 30 January 2018. https://twitter.com/huwlemmey/status/958046775453118464

Marx, Karl. 1978a/1843. For a Ruthless Criticism of Everything Existing. In The Marx-Enge/s Reader, edited by Robert C. Tucker, 12-15. London: W.W. Norton.

Marx, Karl. 1978b/1843. On the Jewish Question. In The Marx-Engels Reader, edited by Robert C. Tucker, 26-52. London: W.W. Norton.

Marx, Karl. 1978c/1844. Economic and Philosophic Manuscripts of 1844. In The Marx-Engels Reader, edited by Robert C. Tucker, 66-125. London: W.W. Norton.

Maddox, David. 2017. EXPOSED: Report CONFIRMS BBC Was "Strongly Biased AGAINST Brexit" in Run-Up to Referendum. Express. Accessed 15 December 2017. https://www.express.co.uk/news/politics/804495/bbc-bias-independent-report-brexit-eureferendum

Mills, Tom. 2017. Media Bias Against Jeremy Corbyn Shows How Politicised Reporting Has Become. The Conversation. Accessed 15 December 2017. https://theconversation.com/media-bias-against-jeremy-corbyn-shows-how-politicisedreporting-has-become-71593

Nagle, Angela. 2017. Kill All Normies: Online Culture Wars from 4chan and Tumblr to Trump and the Alt-Right. Ropley: Zero Books.

Whitham, Ben. 2017. Post-Crash Neoliberalism in Theory and Practice. Political Studies Review, Online First, https://doi.org/10.1177/1478929917720430

Whitham, Ben. 2015. Labour's Choice: Neoliberalism or More Neoliberalism. openDemocracy. Accessed 16 December 2017. https://www.opendemocracy.net/ourkingdom/benwhitham/labour-leadership-election-neoliberalism

Yates, Will. 2017. America's Extremist Battle: Antifa V Alt-Right. BBC News. Accessed 18 December 2017. http://www.bbc.co.uk/news/blogs-trending-39004753

\section{About the Author}

\section{Ben Whitham}

Ben Whitham is Lecturer in International Relations at De Montfort University (DMU) in Leicester. His most recent article "Post-Crash Neoliberalism in Theory and Practice" was published in Political Studies Review in 2017. Ben is currently leading a research pilot project funded by DMU's Centre for Urban Research on Austerity (CURA) exploring "The Intersectional Politics of Austerity and Islamophobia". 